\title{
CHANGES IN SOIL ORGANIC MATTER PARAMETERS DURING THE PERIOD OF 18 YEARS UNDER DIFFERENT SOIL MANAGEMENT PRACTICES
}

\author{
VLADIMÍR ŠIMANSKÝ \\ Slovak University of Agriculture in Nitra, Slovak Republic
}

ŠIMANSKÝ, V.: Changes in soil organic matter parameters during the period of 18 years under different soil management practices. Agriculture (Pol'nohospodárstvo), vol. 62, 2016, no. 4, pp. 149-154.

\begin{abstract}
Quantity and quality of soil organic matter (SOM) is very important from view point of sustainable agriculture; therefore, during the years 1994-2011, the influence of different soil management practices on changes in SOM parameters in loamy Haplic Luvisol was evaluated in a field experiment in the locality of Dolná Malanta. The field experiment included two types of soil tillage - (1) conventional tillage (CT) and (2) reduced tillage (RT) - and also two treatments of fertilisation - (1) crop residues together with added NPK (nitrogen, phosphorus and potassium) fertilisers (CR + NPK) and (2) added NPK fertilisers. Contents of humic substances (HS) and fulvic acids (FA) under RT increased by $1.6 \%$ and $4.4 \%$, respectively, compared to CT during the years 1994-2011. On the other hand, contents of humic acids (HA), HA-to-FA ratios, colour quotient of HS and colour quotient of HA under CT increased by $2.0 \%, 2.5 \%, 1.8 \%$ and $2.3 \%$, respectively, compared to RT. In CT and RT, HS declined at an average speed of $0.33 \%$ and $0.53 \%$ per year, respectively. In CR + NPK treatments and application, only NPK fertiliser caused a decline of HS at an average speed of $0.52 \%$ and $0.33 \%$ per year, respectively. In CT, RT and CR + NPK treatments, the linear trends (statistical significant) in decline of FA were observed. All in all, the CT had a slightly better effect on the quality of SOM, whilst the stability of SOM was improved by RT. Applications of mineral fertilisers along with crop residues resulted in better quality but lower stability of SOM.
\end{abstract}

Key words: soil tillage; fertilisation; humic substances, humic and fulvic acids, tillage

A key element of soil quality is soil organic matter (SOM) (Reeves 1997). The content of SOM is the result of a balance between the processes of mineralisation and humification. Changes in the landscape related to tillage and land use significantly affect the carbon cycle at the regional level as well as globally (Lal 2002). The rate of SOM decline varies depending on the soil type, tillage, crop and climate system (Nardi et al. 2004; Derpsch et al. 2014).

As mentioned earlier, agro-technical operations and environmental changes modify the amount and turnover of SOM. Accumulation and distribution of organic $\mathrm{C}$ in soil is affected by different tillage practices and time after initiation of tillage. Generally, intensive tillage systems are the main reason of SOM decline (Norton et al. 2012; Khorramdel et al. 2013). Ismail et al. (1994) observed a decrease in organic $\mathrm{C}$ during the first 5 years because of soil cultivation; however, organic $\mathrm{C}$ was higher in notill (NT) than that in mouldboard ploughing (MP) system. Šoltýsová and Danilovič $(2007,2008)$ observed higher content of humic substances (HS) in conventional tillage (CT) than in NT and SOM quality in CT was better when compared to that of NT. Several authors (Paré et al. 1999; Dou \& Hons 2006) showed that the quality of SOM in cultivated soil is better; therefore, humus has higher portion of condensed structure units that are resistant to microbial attack. Conservation tillage and residue management are the options for enhancing soil or- 
ganic carbon stabilisation (Choudhury et al. 2014). High residue-producing crops in combination with NT increase SOM (Havlin et al. 1990), whilst SOM declines with low residue-producing crops in combination with MP (Edwards et al. 1992). Crop residues have residual effects on crop growth, organic $\mathrm{C}$ and $\mathrm{N}$ availability (Christensen $e t$ al. 1994). Crop residue retention is also important for sequestering soil organic carbon (SOC), controlling soil erosion and improving soil quality (Blanco-Canqui \& Lal 2007). Mineral fertilisers can also improve residue quantity and quality, but this does not necessarily increase the SOC pool. However, fertilisers may also decrease SOC concentration when compared to unfertilised soil (Halvorson et al. 2002). Improving the quantity and quality of SOM in arable soils is important if requirements of sustainable agriculture are to be satisfied.

Content of SOC in different soil tillage and fertiliser treatments in the Haplic Luvisol have been assessed (Šimanský 2017); however, contents of HS and other quantitative parameters of SOM in these treatments were not evaluated. Therefore, the objective of this paper was to determine the effects of differing tillage and fertilisation practices on changes in SOM parameters (mainly qualitative) of the intensively farmed Haplic Luvisol over the period of 18 years.

The study was conducted in the experimental station of the Slovak University of Agriculture Nitra, Dolná Malanta Nitra $\left(48^{\circ} 19^{\prime} 00^{\prime \prime} \mathrm{N} ; 18^{\circ} 09^{\prime} 00^{\prime \prime}\right.$ E). The experimental area was flat, with a slight inclination towards south. The geological substratum consisted of little previous rocks (biotite quartz diorite, triassic quartzites with phyllite horizonts, crinoid limestones and sandy limestone) with high quantities of fine materials. Young Neogene deposits were composed of various clays, loams and sand gravels on which loess was deposited in the Pleistocene epoch. The soil was loamy Haplic Luvisol (WRB 2006) and, on an average, in A horizon, it contained $12.9 \mathrm{~g} / \mathrm{kg}$ of SOC, $14.7 \mathrm{cmol} / \mathrm{kg}$ of CEC and the base saturation percentage was $92.6 \%$. On an average, the soil $\mathrm{pH}$ (soil: water $=1: 2.5$ ) was 6.96. The average annual temperature was $9.8^{\circ} \mathrm{C}$, and the precipitations per year were $573 \mathrm{~mm}$ (Španik et al. 2002). Monthly mean temperature in January was from -1 to -3 , and on an average, the temperature for the vegetation (April-September) was $15-17^{\circ} \mathrm{C}$. Mean annual rainfall was $540 \mathrm{~mm}$, and the rainfall between June and August was in the range 150-200 $\mathrm{mm}$.

In 1994, a field experiment was established by the Department of Plant Production of SAU-Nitra. Two tillage treatments replicated four times were (1) conventional tillage (CT), which consisted of MP (22-25 cm deep) in autumn and then followed by disking, rolling/levelling and planting, and (2) reduced tillage (RT), which consisted of disking to a depth of $10-12 \mathrm{~cm}$ in autumn, followed by rolling/ levelling and planting. The two fertilisation treatments replicated four times were (1) crop residues added together with NPK (nitrogen, phosphorus and potassium) fertilisers (CR + NPK) and (2) added NPK fertilisers. In CR + NPK treatments, the crop residues were incorporated into the soil. The fertilisers used were mainly nitre ammonium with dolomite (LAV 27), potassium chloride and triple superphosphate. The doses of NPK were calculated by the balance method. The field experiment had the following crop rotation: (1) cowgrass (Trifolium pratense L.), (2) pea (Pisum sativum L. subsp. Hortense (Neitr.), (3) winter wheat (Triticum aestivum L.), (4) maize (Zea mays L.) and (5) spring barley (Hordeum vulgare L.).

Soil samples in all the treatments were collected from the depth of $0-20 \mathrm{~cm}$ in spring during the period of 18 years. For each sampled zone (including all treatments of tillage and fertilisation), six different locations were chosen randomly. On each location, soil samples were collected and mixed to produce an average sample. Soil samples were dried at laboratory temperature and grinded. The quantification of the HS, humic acids (HA) and fulvic acids (FA) was done by the method described by Belchikova and Kononova (Dziadowiec \& Gonet 1999). The method is based on the extraction and separation of the alkali-soluble HA and FA using $0.1 \mathrm{M} \mathrm{NaOH}$ and separation of HA from FA using $1 \mathrm{~N} \mathrm{HCl}$. Based on the contents of HA and FA, HA-to-FA ratios were calculated. The absorbance of HS and HA was measured at 465 and $650 \mathrm{~nm}$ (using a Jenway Model 6400 spectrophotometer) to calculate the colour quotients of $\mathrm{HS}\left(\mathrm{Q}^{4 / 6}{ }_{\mathrm{HS}}\right)$ and $\mathrm{HA}\left(\mathrm{Q}^{4 / 6}{ }_{\mathrm{HA}}\right)$. Statistical analysis was performed using the Statgraphics Centurion XV.I (Statpoint Technologies, Inc., USA) to 
determine the statistical significance of treatment effects. Differences in means (HS, HA, FA, HA-toFA ratios, $\mathrm{Q}_{\mathrm{HS}}^{4 / 6}$ and $\left.\mathrm{Q}^{4 / 6}{ }_{\mathrm{HA}}\right)$ were determined by calculating the least significant difference (LSD) at the $5 \%$ level. To evaluate the trends of the SOM dynamics during the years 1994-2011, the simple linear regression model was used.

Means of SOM parameters in different soil management practices in Haplic Luvisol during the years 1994-2011 are shown in Figure 1A and B. Contents of HS and FA under RT increased by $1.6 \%$ and $4.4 \%$, respectively, compared to CT. On the other hand, during the period of 18 years of this study, the contents of HA, HA-to-FA ratios, $\mathrm{Q}^{4 / 6}{ }_{\mathrm{HS}}$ and $\mathrm{Q}^{4 / 6}{ }_{\mathrm{HA}}$ under $\mathrm{CT}$ increased by $2.0 \%, 2.5 \%, 1.8 \%$ and $2.3 \%$, respectively, compared to RT. As reported by Zhang et al. (1988), soil tillage has significant influence on the contents of HS, but our results showed that soil tillage in Haplic Luvisol did not produce significant changes in SOM parameters (Figure $1 \mathrm{~A}$ and B). Incorporation of crop residues into the soil was shown to increase SOM (Sharma \& Acharya 2000; Abdullah 2014). Our data on Haplic Luvisol during the 18-year study period did not confirm this knowledge. The application of NPK fertilisers does not significantly increase the contents of HS, HA and HA-to-FA ratios, but, on the other hand, it decreased (no significant) the contents of FA and humus stability compared to CR + NPK.

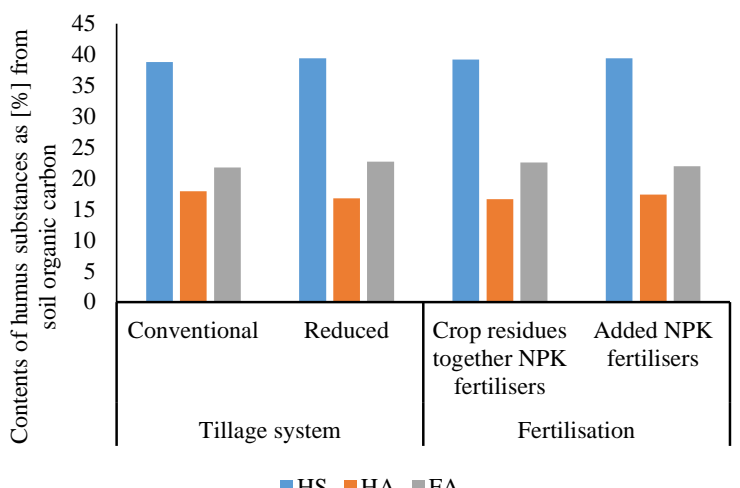

$\because \mathrm{HS} \square \mathrm{HA} \square \mathrm{FA}$
The effects of different soil management practices (tillage and fertilisation) on SOM dynamics were assessed during the 18-year study period. Indeed, notwithstanding the high variability of SOM amongst the years, in all soil management practices, we observed a significant linear decline of extracted HS. Several authors also confirmed the loss of SOM by intensive tillage systems (Franzluebbers et al. 1995; Dou \& Hons 2006) and usage of fertilisers (Halvorson et al. 2002; Šimanský 2014). Higher oxidation of HS decreases the content of $\mathrm{C}$ and $\mathrm{H}$ but increases $\mathrm{O}$ in both HA and FA (Miglierina \& Rosell 1995). In CT and RT, HS was declined at an average speed of $0.33 \%$ and $0.53 \%$ per year, respectively. During the 18 -year study period, a decrease of $5.94 \%$ and $9.54 \%$ extracted HS in the soil was observed in CT and RT treatments, respectively. Incorporation of crop residues together with NPK and the application of NPK fertiliser only caused a decline of HS at an average speed of $0.52 \%$ and $0.33 \%$ per year, respectively. During the 18 years of the study, these represented a decrease of $9.36 \%$ and $5.94 \%$ HS in the soil in CR+NPK and NPK treatments, respectively. It is very surprising because according to these findings in Haplic Luvisol, rather reduced than conventional as well as added crop residues with NPK than only NPK decreased more intensively contents of HS. Similarly, Kubát et al. (2002) found contradictory results in the extraction

Figure 1. Analyses of variance of soil organic matter parameters

HS - humic substances; HA - humic acids; FA - fulvic acids; HA:FA - humic acids to fulvic acids ratio; $\mathrm{Q}_{\mathrm{HS}}$ - colour quotient of humic substances; $\mathrm{Q}_{\mathrm{HA}}$ - colour quotient of humic acids

There are no statistically significant differences according to $L S D$ test. 
of HS. HS form a more conservative SOM fraction that is strongly site specific. The extraction of HS by the application of fresh organic matter into soil was decreased (Zaujec \& Šimanský 2006), because easy decomposable and instable sources from organic matter added to soil were available and they were influenced by the extraction. The contents of HA did not decrease significantly during the 18-year period in all soil management practices. In CT, RT and CR + NPK treatments, the linear trends (statistical significant) in the decline of extracted FA were observed
(Table 1). Since FA content decreased faster than the HA, it led to a slight improvement in the quality of humus in all soil management practices; however, this did not have a statistically linear course. Several authors (Paré et al. 1999; Dou \& Hons, 2006) showed the fact that the quality of SOM in cultivated soil is better. Results of Šimanský (2014) showed that NPK fertilisers had positive effect on statistically significant increase (linear) in humus quality (evaluated by HA-to-FA ratios). During the 18-year study period, the humus stability (based on $\mathrm{Q}^{4 / 6}{ }_{\mathrm{HS}}$

$\mathrm{T}$ a

Trends in the SOM parameters during the years 1994-2011 ( $y=$ SOM parameters $)$ with time $(x=$ years $)$

\begin{tabular}{|c|c|c|c|c|}
\hline Treatments & Equations & $\mathrm{R}^{2}$ & Trend & $\begin{array}{c}\text { Level of } \\
\text { significance }\end{array}$ \\
\hline \multicolumn{5}{|c|}{ HS } \\
\hline Conventional tillage & $y=-0.33 x+699.9$ & 0.1459 & Decrease & ++ \\
\hline Reduced tillage & $y=-0.53 x+1,090.4$ & 0.2519 & Decrease & +++ \\
\hline Crop residues together with added NPK fertilisers & $y=-0.52 x+1,074.4$ & 0.2437 & Decrease & ++ \\
\hline Added NPK fertilisers & $y=-0.33 x+693.8$ & 0.1282 & Decrease & + \\
\hline \multicolumn{5}{|c|}{ HA } \\
\hline Conventional tillage & $\mathrm{y}=-0.11 \mathrm{x}+239.2$ & 0.0459 & Decrease & n.s. \\
\hline Reduced tillage & $y=-0.13 x+281.7$ & 0.0677 & Decrease & n.s. \\
\hline Crop residues together with added NPK fertilisers & $y=-0.14 x+291.4$ & 0.0876 & Decrease & n.s. \\
\hline Added NPK fertilisers & $y=-0.10 x+206.6$ & 0.0411 & Decrease & n.s. \\
\hline \multicolumn{5}{|c|}{ FA } \\
\hline Conventional tillage & $y=-0.22+460.6$ & 0.1009 & Decrease & + \\
\hline Reduced tillage & $y=-0.39 x+808.7$ & 0.1391 & Decrease & ++ \\
\hline Crop residues together with added NPK fertilisers & $y=-0.38 x+783.1$ & 0.1335 & Decrease & + \\
\hline Added NPK fertilisers & $y=-0.23 x+486.3$ & 0.0716 & Decrease & n.s. \\
\hline \multicolumn{5}{|c|}{ HA:FA } \\
\hline Conventional tillage & $y=0.0031 x-5.4$ & 0.0109 & Increase & n.s. \\
\hline Reduced tillage & $y=0.0044 x-8.2$ & 0.0178 & Increase & n.s. \\
\hline Crop residues together with added NPK fertilisers & $y=0.0056 x-10.5$ & 0.0296 & Increase & n.s. \\
\hline Added NPK fertilisers & $y=0.0015 x-2.2$ & 0.0026 & Increase & n.s. \\
\hline \multicolumn{5}{|c|}{$\mathrm{Q}_{\mathrm{HS}}^{4 / 6}$} \\
\hline Conventional tillage & $y=-0.016 x+37.04$ & 0.0177 & Decrease & n.s. \\
\hline Reduced tillage & $y=0.003 x-0.84$ & 0.0004 & Increase & n.s. \\
\hline Crop residues together with added NPK fertilisers & $y=-0.001 x+6.18$ & 0.0001 & Decrease & n.s. \\
\hline Added NPK fertilisers & $y=-0.004 x+12.33$ & 0.0011 & Decrease & n.s. \\
\hline \multicolumn{5}{|c|}{$\mathrm{Q}_{\mathrm{HA}}^{4 / 6}$} \\
\hline Conventional tillage & $y=0.004 x-3.28$ & 0.0017 & Increase & n.s. \\
\hline Reduced tillage & $y=0.015 x-26.35$ & 0.0366 & Increase & n.s. \\
\hline Crop residues together with added NPK fertilisers & $y=0.010 x-16.93$ & 0.0144 & Increase & n.s. \\
\hline Added NPK fertilisers & $y=0.009 x-13.96$ & 0.0141 & Increase & n.s. \\
\hline
\end{tabular}

HS - humic substances; HA - humic acids; FA - fulvic acids; HA:FA - humic acids to fulvic acids ratio; $\mathrm{Q}^{4 / 6}{ }_{\mathrm{HS}}$ - colour quotient of humic substances; $\mathrm{Q}^{4 / 6}{ }_{\mathrm{HA}}$ - colour quotient of humic acids; n.s. - non-significant; ${ }^{++} P \leq 0.001 ;{ }^{++} P \leq 0.01 ;{ }^{+} P \leq 0.05$ 
and $\mathrm{Q}^{4 / 6}$ ) fluctuated, however, without statistical significance (Table 1). Fertilisation has a significant impact on the stability of humus (Tobiašová \& Šimanský 2009) because added nutrients are the sources for microorganism that are responsible for the decomposition of SOM. Manure (Riffaldi et al. 1998) and also the fresh crop residues added to the soil (Zaujec \& Šimanský 2006) are an important source of labile organic matter that reduces the humus stability. Also, application of fertilisers can reduce the stability of the SOM (Tobiašová \& Šimanský 2009; Šimanský 2014).

The results clearly showed that in all soil management practices, no significant changes in the SOM parameters were observed. CT had a slightly better effect on the quality of SOM, whilst the stability of organic matter was improved by reduced tillage. Applications of mineral fertilisers along with crop residues resulted in better quality but lower stability of organic matter. The results showed that the period of 18 years is not a sufficient time span for the evaluation of changes in SOM quality under different soil management practices investigated in Haplic Luvisol. For responsible assessment of the quality of the soil, there are also several soil properties (chemical and physical) that have to be quantified.

\section{REFERENCES}

ABDUlLAH, A.S. 2014. Minimum tillage and residue management increase soil water content, soil organic matter and canola seed yield and seed oil content in the semiarid areas of Northern Iraq. In Soil \& Tillage Research, vol. 144, pp. 150-155. DOI: 10.1016/j. still.2014.07.017

BLANCO-CANQUI, H. - LAL, R. 2007. Soil structure and organic carbon relationships following 10 years of wheat straw management in no-till. In Soil \& Tillage Research, vol. 95, no. 1-2, pp. 240-254. DOI: 10.1016/j.still.2007.01.004

CHOUDHURY, S.G. - SRIVASTAVA, S. - SINGH, R. CHAUDHARI, S.K. - SHARMA, D.K. - SINGH, S.K. - SARKAR, D. 2014. Tillage and residue management effects on soil aggregation, organic carbon dynamics and yield attribute in rice-wheat cropping system under reclaimed sodic soil. In Soil \& Tillage Research, vol. 136, pp. 76-83. DOI: 10.1016/j.still.2013.10.001

CHRISTENSEN, N.B. - LINDEMANN, W.C. - SOSA, E.S. - GILL, L.R. 1994. Nitrogen and carbon dynamics in no-till and stubble mulch tillage systems. In Agronomy Journal, vol. 86, pp. 298-303. DOI: 10.2134/agronj1994.00021962008600020017x
DERPSCH, R. - FRANZLUEBBERS, A.J. - DUIKER, S.W. - REICOSKY, D.C. - KOELLER, K. - STURNY, W.G. - SÁ, J.C.M. - WEISS, K. 2014. Why do we need to standardize no-tillage research? In Soil \& Tillage Research, vol. 137, pp.16-22. DOI: 10.1016/j. still.2013.10.002

DOU, F. - HONS, F.M. 2006. Tillage and nitrogen effects on soil organic matter fraction in Wheat-based systems. In Soil Science Society of American Journal, vol. 70, pp. 1896-1905. DOI: 10.2136/sssaj2005.0229

DZIADOWIEC, H. - GONET, S.S. 1999. Przewodnik metodyczny do badań materii organicznej gleb [Methodical guide-book for soil organic matter studies]. Prace Komisji Naukowych Polskiego Towarzystwa Gleboznawczego, N. 120, Komisja chemii gleb, Zespół Materii Organicznej Gleb, N II/16, 65 p.

EDWARDS, J.H. - WOOD, C.W. - THURLOW, D.L. RUF, M.E. 1992. Till-age and crop rotation effects on fertility status of Hapludult soil. In Soil Science Society of American Journal, vol. 56, pp. 1577-1582. DOI: $10.2136 /$ sssaj $1992.03615995005600050040 x$

FRANZLUEBBERS, A.J. - HONS, F.M. - ZUBERER, D.A. 1995. Soil organic carbon, microbial biomass, and mineralizable carbon and nitrogen in sorghum management systems. In Soil Science Society of American Journal, vol. 59, pp. 460-466. DOI: 10.2136/ sssaj1995.03615995005900020027x

HALVORSON, A.D. - WIENHOLD, B.J. - BLACK, A.L. 2002. Tillage, nitrogen, and cropping system effects on soil carbon sequestration. In Soil Science Society of American Journal, vol. 66, pp. 906-912. DOI: $10.2136 /$ sssaj2002.9060

HAVLIN, P.J. - KISSEL, D.E. - MADDUX, L.D. - CLAASSEN, M.M. - LONG, J.H. 1990. Crop rotation effect on soil organic carbon and nitrogen. In Soil Science Society of American Journal, vol. 54, pp. 448-452. DOI: 10.2136/sssaj 1990.03615995005400020026x

ISMAIL, I. - BLEVINS, R.L. - FRYE, W.W. 1994. Long term no tillage effects on soil properties and continuous corn yields. In Soil Science Society of American Journal, vol. 58, pp. 193-198. DOI: 10.2136/ sssaj1994.03615995005800010028x

IUSS Working Group WRB. 2006. World reference base for soil resources 2006. 2nd edition. World Soil Resources Reports No. 103. Rome : FAO, pp. 145.

KHORRAMDEL, S. - KOOCHEKI, A. - MAHALLATI, M.N. - KHORASANI, R. - GHORBANI, R. 2013. Evaluation of carbon sequestration potential in corn fields with different management systems. In Soil \& Tillage Research, vol. 133, no. 1-2, pp. 25-31. DOI: 10.1016/S0167-1987(97)00038-X

KUBÁT, J. - CERHANOVA, D. - NOVAKOVA, J. - LIPAVSKY, J. 2002. Soil organic matter content and quality in polyfactorial field experiments. In Archiv für Acker und Pflanzenbau und Bodenkunde, vol. 48, pp. 131-140. DOI: 10.1080/03650340214167

LAL, R. 2002. Soil carbon dynamics in cropland and rangeland. In Environmental Pollution, vol. 116, no. 3, pp. 353-362. DOI: 10.1016/S0269-7491(01)00211-1

MigLieRinA, A.M. - ROSELL, R.A. 1995. Humus quantity and quality of an Entic Haplustoll under di- 
fferent soil-crop management systems. In Communicacion in Soil Science and Plant Analysis, vol. 26, pp. 19-20.

NARDI, S. - MORARI, F. - BERTI, A. - TOSONI, M. GIARDINI, L. 2004. Soil organic matter properties after 40 years of different use of organic and mineral fertilisers. In European Journal of Agronomy, vol. 21, no. 3, pp. 357-367. DOI: 10.1016/j.eja.2003.10.006

NORTON, J.B. - MUKHWANA, E.J. - NORTON, U. 2012. Loss and recovery of soil organic carbon and nitrogen in a semiarid agroecosystem. In Soil Science Society of American Journal, vol. 76, pp. 505-514. DOI: $10.2136 /$ sssaj2011.0284

PARE, T. - DINEL, H. - MOULIN, A.P. - TOWNLEY-SMITH, L. 1999. Organic matter quality and structural stability of a Black Chernozemic soil under different manure and tillage practices. In Geoderma, vol. 91, no. 3-4, pp. 311-326. DOI: 10.1016/S00167061(99)00011-7

REEVES, D.W. 1997. The role of soil organic matter in maintaining soil quality in continuous cropping system. In Soil \& Tillage Research, vol. 43, no. 1-2, pp. 131-167. DOI: 10.1016/S0167-1987(97)00038-X

RIFFALDI, R. - LEVI-MINZI, A. - SAVIOZZI, A. - BENETTI, A. 1998. Adsorption on soil of issolved organic carbon from farmyard manure. In Agriculture, Ecosystems \& Environment, vol. 69, no. 2, pp. 113119. DOI: 10.1016/S0167-8809(98)00097-8

SHARMA, P.K. - ACHARYA, C.L. 2000. Carry-over of residual soil moisture with mulching and conservation tillage practices for sowing of rainfed wheat (Triticum aestivum L.) in north-west India. In Soil \& Tillage Research, vol. 57, no. 1-2, pp. 43-52. DOI: 10.1016/S0167-1987(00)00141-0

ŠIMANSKÝ, V. 2014. Ako hnojenie ovplyvňuje zadržiavanie uhlíka v pôde? [How fertilization affects carbon sequestration in the soil?]. In Agrochémia, vol. 54, no. 2 , pp. $13-17$.

ŠIMANSKÝ, V. 2017. Is the period of 18 years sufficient for an evaluation of changes in soil organic carbon under a variety of different soil manage- ment practices? In Communications in Soil Science and Plant Analysis, vol. 48, no. 1, pp. 37-42. DOI: 10.1080/00103624.2016.1253717

ŠOLTYSOVÁ, B. - DANILOVIČ, M. 2007. Zmeny obsahu a kvality humusu $\mathrm{v}$ závislosti od rozdielneho obrábania pôdy [Changes of contents and quality of humus in dependence on different tillage]. In Agriculture (Pol'nohospodárstvo), vol. 53, no. 3, pp. $132-$ 140.

ŠOLTYSOVÁ, B. - DANILOVIČ, M. 2008. The influence of different tillage systems on content and distribution of nutrients and organic components in soil. In Ecomit : Proceedings of $5^{\text {th }}$ International Scientific Conference on Sustainable Farming Systems. Piešt'any : Slovak Agricultural Research Centre - Research Institute of Plant Production, pp. 33-36.

ŠPÁNIK, R. - REPA, Š. - ك̌IŠKA, B. 2002. Agroklimatické a fenologické pomery Nitry [Agro-climatic and phenological conditions in Nitra]. Nitra : SPU, pp. 39.

TOBIAŠOVÁ, E. - ŠIMANSKÝ, V. 2009. Kvantifikácia pôdnych vlastností a ich vzájomných vzt'ahov ovplyvnených antropickou činnostou [Quantification of soil properties and their interrelationships effected by antropic activity]. Nitra : SPU, pp. 113.

ZAUJEC, A. - ŠIMANSKÝ, V. 2006. Vplyv biostimulátorov rozkladu rastlinných zvyškov na pôdnu štruktúru a organickú hmotu pôdy [Influence of biostimulators decomposition of plant residues on soil structure and soil organic matter]. Nitra : SPU, pp. 112.

ZHANG, H. - THOMPSON, H.L. - SANDOR, J.A. 1988. Compositional differences in organic matter among cultivated and uncultivated Argiudolls and Hapludalfs derived from loess. In Soil Science Society of American Journal, vol. 52, pp. 216-222. DOI: 10.2136/ sssaj1988.03615995005200010037x

Received: November 4, 2016 